\title{
Correction to: Humanistic and Economic Burden of Blindness Associated with Retinal Disorders in a Brazilian Sample: A Cross-Sectional Study
}

\author{
Nilceia Lopes - Leticia Lucia dos Santos Dias - Marcos Ávila - Ricardo Miguel Japiassú • Cristina Muccioli • \\ Arnaldo Furman Bordon · Tiago Eugênio Arantes · Tatiana Tanaka · João Jorge Nassaralla Júnior · \\ Antonio Marcelo Casella $\cdot$ Márcio Bittar Nehemy $\cdot$ Magno Ferreira $\cdot$ Rogério Furquim Mauad
}

Published online: July 8, 2021

(c) Springer Healthcare Ltd., part of Springer Nature 2021

Correction to: Adv Ther

https://doi.org/10.1007/s12325-021-01672-3

In the original article, there are few errors as presented as below.

Table 1: lines related to monthly household income (USD). Column one, rows two, three and four were published as "520.39-1040.80, 1040.79-2601.90 and 2601.89-5203.90 respec-

The original article can be found online at https://doi. org/10.1007/s12325-021-01672-3.

N. Lopes $(\bowtie) \cdot$ R. F. Mauad

Novartis Biociências S.A., São Paulo, SP, Brazil

e-mail: nilceia.lopes@novartis.com

L. L. d. S. Dias

ANOVA Consultoria em Saúde Ltda, Rio de Janeiro, RJ, Brazil

\section{M. Ávila}

Centro Brasileiro de Cirurgia de Olhos (CBCO),

Goiânia, GO, Brazil

R. M. Japiassú

Department of Ophthalmology, Hospital

Universitário Pedro Ernesto, Rio de Janeiro, RJ,

Brazil

C. Muccioli

Department of Ophthalmology, Hospital São Paulo - Universidade Federal de São Paulo, São Paulo, SP, Brazil

\section{A. F. Bordon}

Department of Retina, Hospital Oftalmológico de

Sorocaba, Sorocaba, SP, Brazil tively. These should instead be $">520.40-1040.80, \quad>1040.80-2601.90$ and $>2601.90-5203.90 "$ ".

In the first paragraph of page 7 , the statement "...fundoscopy was reported by 133 $(81.3 \%) \ldots$... should read "...fundoscopy was reported by $113(81.3 \%)$...".

The last paragraph on page 7 the sentence "Furthermore, 38 (36\%) subjects observed income reduction due to blindness.", should read "Furthermore, 38 (26\%) subjects observed income reduction due to blindness".

\section{T. E. Arantes}

Department of Ophthamology, Fundação Altino Ventura, Recife, PE, Brazil

\section{T. Tanaka}

Department of Ophthalmology, Hospital das Clínicas da Faculdade de Medicina da Universidade de São Paulo, São Paulo, SP, Brazil

\section{J. J. Nassaralla Júnior}

Department of Retina and Vitreous, Instituto de Olhos de Goiânia, Goiânia, GO, Brazil

\section{A. M. Casella}

Andi Eyes Clinica Oftalmológica, Londrina, PR, Brazil

M. B. Nehemy

Department of Ophthalmology, Universidade Federal de Minas Gerais, Belo Horizonte, MG, Brazil

M. Ferreira

Department of Ophthalmology, Hospital Brasil Central (HBC), Uberlândia, MG, Brazil 
Table 3: the row 'color vision' under 'scales, the mean value was originally published as '48.4'. This value should be ' 4.4 '.

Table 5: the row 'retired due to another reason', the \% was originally published 55.1 . This value should be 52.0 .
Tables 1, 5 and 6: In the notes was published "1 USD = 3.03 BRL", should be " 1 USD $=3.04$ BRL". The original article has been updated. 